\title{
INTERAKSI SOSIAL SISWA KELAS XI SMA NEGERI 1 AWANG LAPAI
}

\author{
Sri Erliyanti \\ SMA Negeri 1 Awang Lapai
}

\begin{abstract}
ABSTRAK
Tujuan penelitian ini adalah untuk mengetahui bagaimana interaksi siswa di SMA Negeri 1 Awang Lapai. Metode penelitian ini adalah kualitataif dengan jenis deskriptif. Sumber data penelitian terdiri dari guru wali kelas, guru BK, dan siswa kelas XI. Teknik pengumpulan data penelitian ini menggunakan teknik wawancara mendalam, observasi, dokumentasi dan catatan lapangan. Teknik analisis data meliputi pengumpulan data, penyederhanaan data, penyajian data dan penarikan kesimpulan. Hasil penelitian menunjukkan ada dua tipe proses interaksi yang terjadi pada siswa di Kelas XI yaitu siswa yang aktif dalam berinteraksi dan siswa yang pasif. Akibat proses interaksi tersebut diketahui belum ada masalah serius yang ditimbulkan, namum diketahui terdapat masalah dalam penerimaan kepada siswa yang pasif di kelas. Saran terhadap masalah ini adalah, guru wali kelas agar rutin melakukan kegiatan kelompok diluar pembelajaran, dan guru BK agar memberikan layanan individu kepada siswa yang pasif.
\end{abstract}

Kata Kunci: interaksi sosial, bimbingan dan konseling

\section{PENDAHULUAN}

Interaksi sosial merupakan hubungan individu satu dengan individu lainnya di mana individu satu dengan yang lainnya dapat mempengaruhi individu lain dan terdapat hubungan yang timbal balik (Walgito, 2000 : 65). Sementara menurut Soekanto dalam (Dayakisni, 2003 : 127), mendefinisikan interaksi sosial sebagai hubungan antar orang perorangan dengan kelompok manusia.

Perkembangan sosial merupakan pencapaian kematangan dalam hubungan sosial dan dimaknakan sebagai proses belajar untuk menyesuaikan diri terhadap norma -norma kelompok, oral dan tradisi, melebur diri menjadi satu kesatuan dan saling berkomunikasi serta bekerjasama (Mukhtar et al., 2016). Setiap individu melakukan interaksi sosial dengan linkungannya. Remaja dalam interaksi sosial tersebut berusaha melakukan penyesuaian terhadap lingkunganya.

Remaja melakukan penyesuaian gaya bicara, gaya berpenampilan bahkan melakukan imitasi kepribadian terhadap teman sebaya di lingkungan sekitarnya. Remaja lebih sering berada di luar rumah bersama dengan teman-teman sebaya sebagai kelompok, maka dapatlah dipahami bahwa pengaruh teman-teman sebaya pada sikap, pembicaraan, minat, penampilan dan perilaku lebih besar dari pada pengaruh keluarga.

Secara garis besar kemampuan siswa dalam berinteraksi sosial dapat dikategorikan ke dalam dua kelompok, yaitu siswa yang dapat dikategorikan sebagai siswa yang bisa berinteraksi sosial dengan baik atau pandai bergaul dan sebaliknya yaitu siswa yang mengalami kesulitan bergaul atau individu yang tidak bisa berinteraksi sosial dengan baik. Siswa yang bisa berinteraksi sosial dengan baik biasanya dapat mengatasi berbagai persoalan di dalam pergaulan. Mereka tidak mengalami kesulitan untuk menjalani hubungan dengan teman baru, berkomunikasi secara efektif dengan orang lain, terlibat dalam pembicaraan yang menyenangkan, dan dapat mengakhiri 
pembicaraan tanpa mengecewakan atau menyakiti orang lain.

Anak belajar mengenal dirinya sendiri dan kedudukannya dalam kelompok melalui hubungan interpersonal dengan teman sebaya Pada perkembangan kehidupan sosial, remaja memiliki berbagai macam tugas perkembangan yang harus dilalui agar kehidupan sosial remaja berjalan dengan baik di masa yang akan datang. Salah satu tugas perkembangan sosial remaja adalah membina hubungan sosial dengan teman sebaya dan orang dewasa selain guru dan orangtua (Mukhtar et al., 2016).

Remaja yang telah menjalankan tugas perkembangannya dengan baik mampu berinteraksi dengan teman sebayanya dan diterima dalam kelompok pertemanan, hal sama berlaku pada remaja yang bersikap apatis dan menutup diri sehingga mengalami kendala dalam interaksi sosialnya, remaja tersebut cenderung mengalami penolakan oleh kelompok teman sebayanya. Interaksi sosial adalah kunci dari semua kehidupan sosial oleh karena itu tanpa adanya interaksi sosial tidak akan mungkin ada kehidupan bersama. Interaksi sosial dimaksudkan sebagai pengaruh timbal balik antar individu dengan golongan didalam usaha mereka untuk memecahkan persoalan yang diharapkan dan dalam usaha mereka untuk mencapai tujuannya (Sherlyanita \& Rakhmawati, 2016).

Berdasarkan hasil AUM (Alat Ungkap Masalah) yang telah dilakukan di SMA Negeri 1 Awang Lapai khususnya kelas XI , data statistik menunjukkan bahawa ada $77,8 \%$ masalah yang dihadapi siswa adalah takut tidak diterima dalam lingkungan pertemanan, hal ini yang kemudian memunculkan sikap kurang percaya diri sehingga dapat mempengaruhi kegiatan belajar dan hubungannya dilingkungan sekolah. Anak dengan tingkat interaksi social yang rendah kemungkinan memiliki nilai akademik yang rendah, terutama pada mata pelajaran sosial. Peneliti sempat melakukan wawancara tidak langsung kepada salah seorang siswa yang tidak bergabung dalam gang di sekolahnya, dia mengatakan untuk masuk dalam kelompok gang perkumpulan tidak hanya terjadi di sekolah namun juga di luar sekolah, sedangkan subjek setelah pulang sekolah masih harus mengikuti les hingga malam. Sebab itu subjek tidak tertarik mengikuti kelompok gang dalam sekolah.

Berdasarkan beberapa fakta-fakta masalah yang terjadi pada remaja yang ada dapat diambil kesimpulan bahwa beberapa remaja di lingkungan sekolah tersebut tidak melaksanakan penyesuaian sosial dengan baik. Berdasarkan latar belakang yang peneliti uraikan tersebut, peneliti tertarik untuk melakukan penelitian dengan judul, Studi Deskriptif Interaksi Siswa di SMA Negeri 1 Awang Lapai

\section{METODE}

Metode penelitian ini adalah kualitatif dengan jenis deskriptif. Sumber data penelitian terdiri dari guru wali kelas, guru BK, dan siswa kelas XI. Teknik pengumpulan data penelitian ini menggunakan teknik wawancara mendalam, observasi, dokumentasi dan catatan lapangan. Teknik analisis data meliputi pengumpulan data, penyederhanaan data, penyajian data dan penarikan kesimpulan

\section{HASIL DAN PEMBAHASAN}

Selama penelitian berlangsung, peneliti melihat, mendengar, mencatat dan mendokumentasikan segala sesuatunya yang berkaitan dengan proses interaksi siswa kelas XI SMA Negeri 1 Awang Lapai yang didapati dari data informan penulis yakni guru wali kelas, guru $\mathrm{BK}$, siswa $\mathrm{AB}$ dan siswa DY, data ini kemudian dianalisis dalam pembahasan sesuai dengan rumusan masalah yang ingin di bahas. Maka hasil 
Jurnal Inovasi BK, Volume 2, Nomor 1 Juni 2020 analisis tersebut perlu pembahasan sebagai berikut:

Berdasarkan hasil wawancara antara guru wali kelas, guru $\mathrm{BK}$, siswa $\mathrm{AB}$ dan siswa DY maka terdapat persamaan, kemiripan dan perbedaan sebagai berikut: persamaan yang didapat dari hasil penelitian ialah keempat subjek menjawab 1) kerjasama yang dilakukan siswa di kelas dalam bentuk diskusi kelompok ataupun tugas kebersihan kelas. Persamaan lain adalah, informan mengakui adanya persaingan namun tidak menyebabkan masalah serius. Adapun kemiripan dalam informasi yang dihimpun adalah tindakan guru BK dan guru wali kelas yang mengadakan mediasi jika siswa terlibat masalah. Sedangkan perbedaan ialah terdapat proses interaksi yang berbeda antara siswa $\mathrm{AB}$ dan siswa $\mathrm{DY}$ dalam menjalani kehidupan sosialnya. Siswa AB lebih pasif dibandingkan siswa DY.

Adapun proses interaksi antar siswa dapat dilihat dari kerjasama, persaingan dan pertikaian yang terjadi serta cara mengatasinya. Sedangkan berdasarkan hasil hasil observasi di lapangan menunjukkan pada siswa kelas XI guru BK belum pernah melakukan layanan kelompok maupun individual. Secara garis besar kemampuan siswa dalam berinteraksi sosial dapat dikategorikan ke dalam dua kelompok, yaitu siswa yang dapat dikategorikan sebagai siswa yang bisa berinteraksi sosial dengan baik atau pandai bergaul dan sebaliknya yaitu siswa yang mengalami kesulitan bergaul atau individu yang tidak bisa berinteraksi sosial dengan baik. Siswa yang bisa berinteraksi sosial dengan baik biasanya dapat mengatasi berbagai persoalan di dalam pergaulan. Mereka tidak mengalami kesulitan untuk menjalani hubungan dengan teman baru, berkomunikasi secara efektif dengan orang lain, terlibat dalam pembicaraan yang menyenangkan, dan dapat mengakhiri pembicaraan tanpa mengecewakan atau menyakiti orang lain.
Hasil penelitian tersebut sesuai dengan hasil yang didapat pada saat peneliti melakukan penelitian lapangan seperti wawancara yang ditunjang dengan observasi atau pengamatan serta catatan lapangan dan dokumentasi di sekolahan tersebut. Siswa AB dan siswa DY yang memiliki kemampuan interaksi yang jauh berbeda. Hal itu juga mempengaruhi lingkaran pertemannya. Dalam catatan observasi penelitia, diketahui siswa DY lebih popular di kelas karena banyak memiliki teman, hal ini berbeda dengan siswa $\mathrm{AB}$ yang cenderung memilih menyendiri dan hanya memiliki dua teman di kelas.

Sebagaimana yang dijelaskan Partowisastro (Ahmad 2009: 42) aspek teman sebaya adalah keterbukaan individu dalam kelompok, kerjasama individu dalam kelompok, dan frekuensi hubungan individu dalam kelompok. Dengan adanya keterbukaan maka siswa akan dapat menjalin sebuah hubungan akrab dan mengakibatkan siswa tersebut dapat diterima dalam kelompok manapun. Peran teman sebaya juga memegang peranan unik dalam perkembangan anak karena mereka masuk dalam tingkat umur dan kedewasaan yang kurang lebih sama sehingga teman sebaya bisa memberikan informasi dan perbandingan tentang dunia di luar keluarga.

Sedangkan Suwarni (Maryatun 2013: 45) menjelaskan bahwa faktor yang mempengaruhi interaksi antar teman adalah faktor informasi. Kedekatan antar individu dengan peer group atau kelompok teman sebaya pada masa remaja sangat tinggi, hal ini karena selain ikatan kelompok teman dapat menggantikan ikatan ikatan remaja dengan keluarga, teman sebaya juga merupakan sumber afeksi, memberikan simpati dan pengertian serta saling berbagi pengalaman untuk mencapai otonomi dan independensi. Ikatan tersebut merupakan kecenderungan remaja untuk mengadopsi informasi dari teman-teman sebaya, tanpa memiliki dasar informasi yang diterima 
secara signifikan dari sumber yang lebih terpercaya. Maka hubungan dengan teman sebaya di lingkungan sekolah maupun dalam lingkungan tempat tinggal dapat mempengaruhi keterampilan sosial dan persepsi belajar siswa.

Di sekolah siswa harus dapat mengembangkan kemampuan intelektual dan juga diarahkan supaya menjadi individu yang mandiri dan memiliki kemampuan berkomunikasi yang baik. Komunikasi dapat efektif jika ada keterbukaan antara satu orang dengan orang lain. Komunikasi dengan keterbukaan diri saling berkaitan, secara umum peningkatan keterbukaan diri selalu melibatkan komunikasi yaitu proses penyampaian ide, pendapat, pikiran, dan keahlian dari individu satu ke individu yang lain. Keduanya harus berjalan dengan seimbang.

Sugiyo (2005: 86) menyatakan bahwa pengetahuan tentang diri akan meningkatkan komunikasi dan pada saat yang sama komunikasi dengan orang lain akan meningkatkan pengetahuan tentang diri kita. Berdasarkan pernyataan di atas dapat disimpulkan bahwa kemampuan interaksi sosial dapat memungkinkan seseorang untuk terbuka kepada orang lain sehingga seseorang dapat menerima informasi, pengalaman dan gagasan dari orang lain.

Siswa dapat melakukan kerjasama dengan baik hanya jika dalam pengawasan guru. Artinya jika dibiarkan melakukan tugas sendiri, masih terdapat siswa yang belum mampu melakukan kerjasama dengan baik. Ini dapat menggambarkan adanya bentuk interaksi yang kurang baik antar siswa di kelas, sebab, menggambarkan sikap acuh terhadap tanggung jawab masing-masing.

Hasil wawancara mendalam dengan guru wali kelas mengenai proses interaksi antar siswa dapat diukur melalui bentuk kerjasama di kelas, dalam mengerjakan tugas tidak semua dapat berkerjasama dengan baik jika dibiarkan tanpa pengawasan. Ada saja siswa yang tidak serius dan malah menganggu temannya. Mengerjakan tugas dengan membentuk kelompok belajar, biasanya dengan membentuk kelompok dengan kelompok yang sudah di tentukan guru maka siswa akan lebih mudah belajar. Karena ada sebagian siswa yang segan bertanya secara langsung dengan guru, apabila 1 kelompok ada siswa yang cukup mampu siswa yang lain dapat bertanya dan belajar dari siswa yang lebih mampu untuk agar mudah memahami materi (Wawancara guru bidang studi: 21-31).

\section{KESIMPULAN}

Berdasarkan hasil penelitian dan pembahasan yang telah peneliti lakukan mengenai "Proses Interaksi Siswa Kelas XI di SMA Negeri 1 Awan Lapai diketahui proses interaksi antar siswa dapat dilihat dari kerjasama, persaingan dan pertikaian yang terjadi serta cara mengatasinya. Berdasarkan hasil penelitian menunjukkan kemampuan siswa dalam berinteraksi sosial dapat dikategorikan ke dalam dua kelompok, yaitu siswa yang dapat dikategorikan sebagai siswa yang bisa berinteraksi sosial dengan baik atau pandai bergaul dan sebaliknya yaitu siswa yang mengalami kesulitan bergaul atau individu yang tidak bisa berinteraksi sosial dengan baik.

\section{DAFTAR PUSTAKA}

Arina Fithriyana, Dwi Yuwono Puji Sugiharto, S. 2014. (2012). Jurnal Bimbingan Konseling. Jurnal Bimbingan Konseling.

HANDAYANI, S. (2016). Pengaruh Perhatian Orangtua Dan Minat Belajar. Formatif: JurnalilmiahPendidikan MIPA. https://doi.org/10.1017/CBO978110 7415324.004 
Jurnal Inovasi BK,Volume 2, Nomor 1 Juni 2020

Hurlock, E. (2014). Perkembangan Anak Edisi Keenam Jilid I. Jakarta. In Penerbit Erlangga. https://doi.org/10.1078/0944-200600091

Mukhtar, M., Yusuf, S., \& Budiamin, A. (2016). Program Layanan Bimbingan Klasikal untuk Meningkatkan Self-Control Siswa. PSIKOPEDAGOGIA Jurnal Bimbingan Dan Konseling. https://doi.org/10.12928/psikopedag ogia.v5i1.4473

Deskriptif Komparatif). Ndigenous, Jurnal Ilmiah Berkala Psikologi.

Sherlyanita, A. K., \& Rakhmawati, N. A. (2016). Pengaruh dan Pola Aktivitas Penggunaan Internet serta Media Sosial pada Siswa SMPN 52 Surabaya. Journal of Information Systems Engineering and Business Intelligence.

Mukhtar, M., Yusuf, S., \& Budiamin, A. (2016). Program Layanan Bimbingan Klasikal untuk Meningkatkan Self-Control Siswa. PSIKOPEDAGOGIA Jurnal Bimbingan Dan Konseling. https://doi.org/10.12928/psikopedag ogia.v5i1.4473

Novalia, \& Dayakisni, T. (2013). Perilaku Asertif dan Kecenderungan Menjadi Korban

Bullying.JurnalIlmiahPsikologiTera pan.

https://doi.org/doi.org/10.22219/jipt. v1i1.1366

Setiawati, E. (2010). NTERAKSI SOSIAL DENGAN TEMAN SEBAYA PADA ANAK HOMESCHOOLING DAN ANAK SEKOLAH REGULER (Study

Deskriptif Komparatif). Ndigenous, Jurnal Ilmiah Berkala Psikologi.

Sherlyanita, A. K., \& Rakhmawati, N. A. (2016). Pengaruh dan Pola Aktivitas Penggunaan Internet serta Media
Sosial pada Siswa SMPN 52 Surabaya. Journal of Information Systems Engineering and Business Intelligence.

Sumartono. (2019). Dinamika Perubahan Sosial dalam Teori Konflik. Jurnal Ilmu Komunikasi Dan Bisnis.

Suryawati, I. G. A. A. (2010). Model Komunikasi Penanganan Anak Autis. Jurnal Ilmiah Fakultas Ilmu Sosial Dan Ilmu Politik.

Wahyuni, I. N. (2020). Komunikasi Keluarga Buruh Perempuan. JRK (Jurnal Riset Komunikasi). https://doi.org/10.31506/jrk.v10i2.68 27 